\title{
The Effect of Distance Learning With Learner Center Micro Teaching Model On Student' Teaching Confidence and Teaching Skills
}

\author{
Adrianus Nasar ${ }^{1}$, Melkyanus Bili Umbu Kaleka ${ }^{2}$ \\ Universitas Flores, Indonesia ${ }^{1,2}$ \\ adrianus710@gmail.com ${ }^{1}$, melkycitra15@gmail.com²
}

Received: July $8^{\text {th }}, 2020$. Revised: August $2^{\text {nd }}, 2020$. Accepted: August $10^{\text {th }}, 2020$

\author{
Keywords : \\ Distance Learning; Learner \\ Center Micro Teaching; \\ Teaching Confidence; \\ Teaching Skills
}

\begin{abstract}
The purpose of this study is to find the effect of distance learning through learner center micro teaching model on students' teaching confidence and teaching skills. The research design uses quasi-experimental research and pretest-posttest non controlled group design. The population is physics education students on sixth semester who was programming micro teaching courses. Purposes sampling technic used to get research sample and 31 students take part on this course. Data collected by using questionnaire on variables of teaching confidence and assessment rubric on variables of teaching skills. Teaching confidence and teaching skills are analyzed through normalized-gain and pair sample t-test. Data calculated use SPSS and the result is: 1) teaching confidence has normalized-gain $\langle g\rangle=0,535$ (moderate) and $t=12,336$ $($ sig. $=0,000)$; 2) teaching skills has normalized-gain $\langle g\rangle=$ $0,566$ (moderate) dan $t=9,690$ (sig. $=0,000)$. The result shows the effect of distance learning through learner center micro teaching (LCMT) model can improve teaching confidence and teaching skills of physics education students on FKIP Universitas Flores.
\end{abstract}

\section{INTRODUCTION}

Education program on Faculty of Teacher Training and Education is directed to organize education for prospective teachers in primary and secondary school. In the Law of Republic Indonesia Number 14 of 2005 was mentioned that the teacher is a professional educator who has high competencies and holds hard on the moral values that direct and underlies his action. These competencies obtained through theoretical and practical education processes in an educational institution. According to Azrai et. al., "teachers in the digital era are currently required to have 21 st century teaching skills to meet the needs of superior generation in the new era" [1]. Institution of teaching education is fully responsible to fulfill the needed competencies of teacher in digital era, and micro teaching is one of the many methods for student to practicing teaching skills in the classroom.

Physics education is one of any field study in Universitas Flores that organize the education process for preparing human resources to become a physics teacher. Knowledge is gained through various theories 
related to the teacher profession, and the teaching skills are develop throuh practical experience. As mentioned above, micro teaching is one of any methods for mastering teaching skills in teaching institution. Micro teaching is developed by Allen in the middle of 1963 in Universitas Stanford and then micro teaching has widely used to develop teaching skills in teaching institution [2].

At the end of 2019, the whole world is so busy to solve the spread of COVID-19 by implementing a physical distancing system. All human activities follow health protocols to avoid the wider spread of the COVID-19. Minister of Education makes considerations by carrying out the process of learning from home through distance learning system as a way to prevent the spread of COVID-19. Distance learning is an educational process that focuses on teaching methods and technologies with the aim to implementing the teaching process on the student who is physically absent in traditional educational environments such as classroom and laboratory [3].

Microteaching carried out in 15-20 minutes in the classroom with 5-10 students [4]. The skills developed in micro-teaching are not how long the teaching time is and how much content is delivered but rather prioritizes teaching skills. Because teaching skills that students want to be mastery, then micro-teaching requires steps to implement it and choose which skills to be mastered in teaching practice. The general steps of micro-teaching include guiding and directing, teach, viewing, dialog and discuss, re-teach, evaluation, and transition into integrated teaching [5]. According to Mahmud, microteaching is defined as a teaching practice that has domain as planning, set induction, presentation, questioning, encouraging the students to question, exemplifications, and communication [6]. Thus microteaching is planning and implementing teaching practice gradually to develop teaching skills and be implemented on his peers as students and in a relatively short time.

Bahjat said that microteaching based on an education analysis process to a set of skills and apply this skill, which leads students to learn from trial and error to the acquisition of required teaching skills which become part of the teaching behavior of the student [7]. Students gradually develop their learning skills by using their thinking skills and then implementing them into teaching practices. Herrera et al. suggested that microteaching is a classroom teaching activity after gaining an understanding of the nature of teaching and having received lecturer guidance, where his friends become students [8]. The microteaching cycle includes a plan, teach, feedback, re-plan, re-teach, and re-feedback. These teaching activities are observed by lecturers and recorded using a video recorder which is then used to be a source of evaluation of teaching practices. Peers who act as students, accompanying lecturers, and video recordings become a source of evaluation and feedback for students practicing in reflection. In this case, teaching activities are observed by lectures through recorded videos that students record their teaching practices. Feedback from the lecture is got after the lecture watch and assesses students performance.

The main purposes of micro teaching are: 1) to learn and assimilate new skills under controlled conditions; 2) to master a number of teaching skills; 3) gain confidence in teaching, understand the concepts and principles that underlie microteaching; and 4) can analyze complex teaching processes into important microteaching skills and understand microteaching procedures to develop teaching skills [9]. Students learn how the pedagogical knowledge they have acquired before is used to make students learn in a particular situation. Because microteaching is a cyclic process, its activities are carried out repeatedly, and this will increase the mastery of subject matter knowledge and teaching skills. By mastering knowledge and teaching skills, students may have high confidence in the learning process.

LCMT model proposed by Kilic that aims to develop the student's competency of the prospective teacher. LCMT based on active learning proposed by Kolb (1984), were acquired new knowledge by individuals by doing more than thinking [10]. Active learning is an approach where students participate in the learning process through 4 steps that are observed, reflect, build an abstract concept, and get new experience. Because students actively participate, active learning is student-centered learning that is based on experiential learning where a learner actively acquires knowledge and skills well and is permanently stored [9]. Active learning also based on the principle of constructivism while students use facts to build their knowledge and understanding. According to Dagar and Yadav, constructivism 
emphasizes that knowledge construction rather than knowledge transmission and the recording of new information, new learning builds on prior knowledge, and meaningful learning develops through authentic tasks [11]. The component of the LCMT model is shown in Fig. 1.

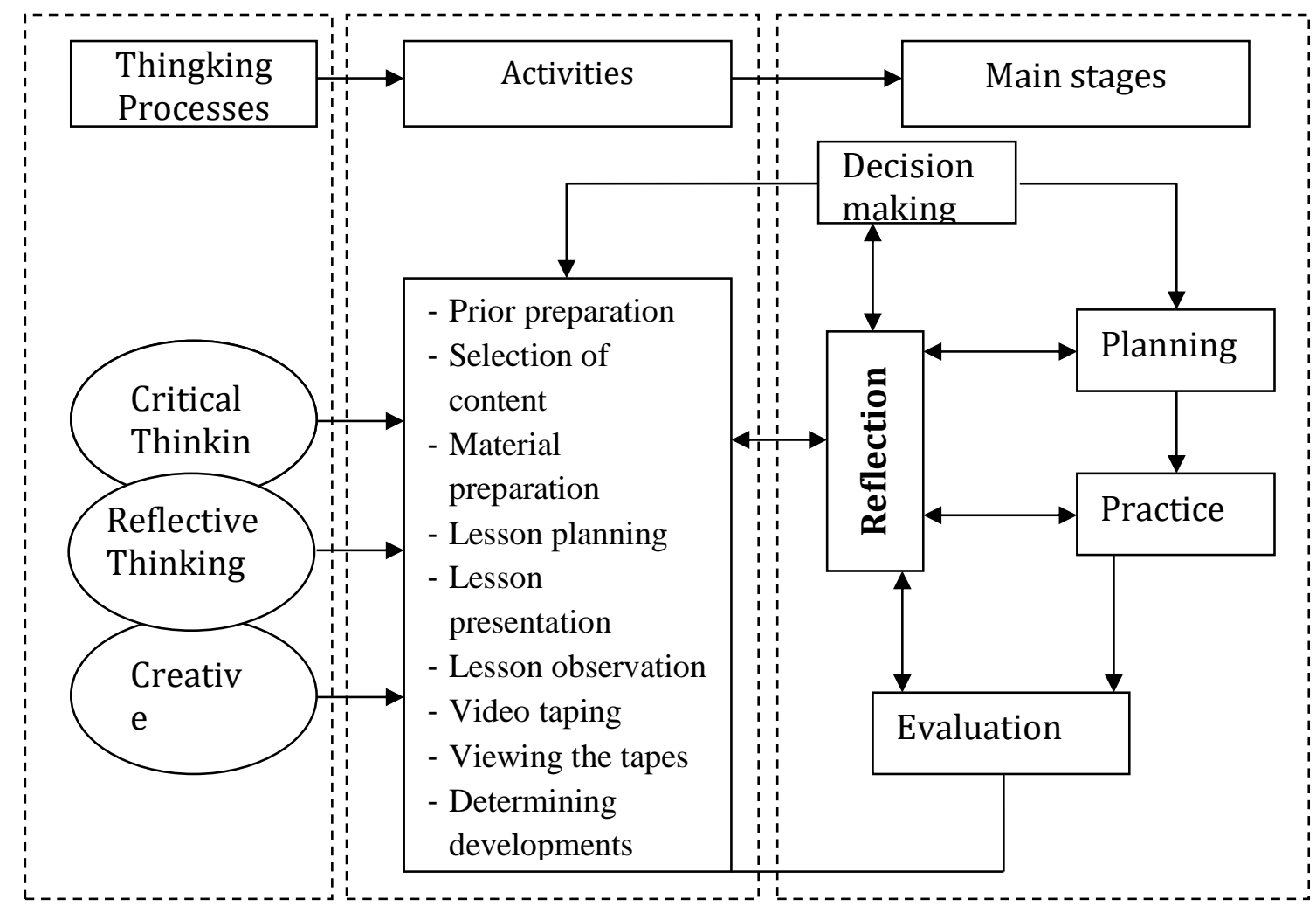

Fig 1. LCMT Model

LCMT model has three main components namely thinking process, activity, and the main stage. At the stage of the thinking process, students learn to form new knowledge and understanding through the activities of critical, reflective, and creative thinking. Through critical thinking, the student analyzes the characteristics of microteaching, discovers the relationship between the parts, and combines the parts into a unity. In this section, students learn the nature of microteaching by reading and examining relevant sources. Students, who study with active learning, will direct themselves to the reflective thinking process. They think about what they know and understand, what they want to know and think about what they think about microteaching. At this time, they find weaknesses and strengths of their thinking ability, and then try to take the opportunity to reduce their weaknesses, and use their strengths to find a concept to be applied to a new situation. In the process of creative thinking, students use concepts that have been agreed to be used in new conditions. Creative thinking overcomes the critical and creative conscious and analyzes what has been done before, has succeeded, and what and how a person has learned. Students understand the nature of microteaching as a whole, how content is represented in pedagogy, and how to measure the results of these microteaching practices. As a result of this thought process, students undertake activities such as making lesson plans, selecting teaching content, selecting learning media, implementing teaching and learning, recording and observing teaching activities, and evaluating the microteaching process. In the LCMT model, students who practice were expected to be active in making decisions, planning, application, and evaluation. Students actively participate in the process of making decisions about what to learn, how to learn, and what kind of assistance is needed, and how to decide about how much has been learned.

The implementation of the LCMT micro teaching model applies the principle of physical distancing during the study period at home due to the Covid-19 outbreak. Lecturers and students are not in the same room physically but apply it in a distance learning system. The distance learning system applies online learning by using communication and information technologies. The lecturer describes the concept and 
The Effect of Distance Learning With Learner Center Micro Teaching Model... Adrianus Nasar, Melkyanus Bili Umbu Kaleka

implementation of micro teaching, teaching skills, the process of recording teaching activities, observing and reviewing activities, and giving feedback. Students are assigned to understand the subject matter and are represented step by step in the learning plan. Before students compile a learning implementation plan, students are asked to describe rationally and logically from the learning plan made and then the learning plan and the results of this description are consulted with a lecturer as a supervisor. The results of the supervising lecturer's assessment of the learning plan, lecturer are sent back to students to make revisions to the lesson plan.

In the next process, students do the teaching practice independently without having friends as students. The implementation and recording of teaching practice are held for 15-20 minutes in the place where the student is located. The results of the recording are duplicated for observing by the supervisor and the students themselves. Observation and evaluation of teaching practices from this video use the same assessment format between lecturers and students and then combined to get feedback. The results of student self-assessment and lecturer assessment are compared with predetermined teaching skills criteria. The results of this evaluation process will be input in the next re-teach process, namely in the re-plan, re-teach, and re-feedback. The LCMT model micro teaching process is carried out repeatedly using different subject matter or content.

The implementation of micro teaching helps students to increase self confidence levels and teaching skills of teacher candidates [12]. Teaching confidence is defined as the belief of a student about his ability to teach subjects. Someone's confidence in teaching content can be described as self-efficacy [13]. Research on the influence of micro teaching on various aspects has been carried out by many researchers. The results showed that the practice of micro teaching has a positive influence on teaching skills [14] [15] [16]. According to Savas, participants' responses showed that micro-teaching video activity had a positive impact on improving participants' teaching skills [17]. Students' reflection was related to the openness of the task, as they had to make decisions about many different aspects of their teaching, and increased knowledge of the possibilities for productive reflection during planning may also contribute to understanding of how teacher educators may make reflection an integral part of microteaching [18]. Feedback has been found to be effective in improving the general teaching competence of student [15] [19]. Through the teaching section, students organize teaching practices well, and they were very communicatively with planning the process, and feel that it can be applied to normal classroom situations and focused on specific skills [20]. Micro teaching also has significant results on teaching skills, and this influence can be observed through the act of opening a lesson, managing class, managing time and planning, effective communication, and making lesson conclusions, and all this in turn affects teaching confidence [21].

The results also showed that micro-teaching can improve students' abilities and performances in terms of teaching skills [22]. In addition, micro teaching can positively influence teacher teaching skills before real teaching, self-efficacy, anxiety, and critical thinking skills and dispositions, all of which are teacher education competencies [23]. The other study also showed that the anxiety faced would encourage participants to self-awareness and increase their confidence [20]. Micro teaching has a positive effect on increasing self-confidence, teaching experience, teaching lessons effectively, communicating effectively, how to conclude lessons, class management, planning and time management [24].

Micro teaching is a trial and error method in combining content knowledge and pedagogy knowledge to develop the teaching skills of prospective teacher students. The purpose of micro teaching is not what students must teach but rather how to teach. The implementation is a cycle that allows students to reflect on the teaching practice process. The LCMT model applies reflection activities in its cycle or stages of implementation. The implementation of micro teaching requires some knowledge and understanding to be displayed in teaching activities. Implementation of students' knowledge and understanding in the form of activities is a skill developed in micro teaching. The skills developed in micro teaching include engage students' attention, using learning strategies, and managing classes. The ability of students practicing in attracting attention and encouraging students to learn, use appropriate learning strategies, and control the behavior of students (peer students) in the learning process will determine teaching 
confidence. From the statement above, it can be concluded that the effect of the LCMT model through learning from home can increase teaching confidence and teaching skills of students.

\section{METHOD}

The research on the LCMT model was conducted on the sixth semester students of the Physics Education Study Program at the Faculty of Teacher Training and Education at the University of Flores who were programming micro teaching courses. This research is a quasi-experimental study using one group pretest-posttest design without a control group. The experimental design used is shown in Table 1.

Tabel 1 Experimental Design

\begin{tabular}{cccc}
\hline Group & Pretest & Treatment & Posttest \\
\hline $\mathrm{G}$ & $\mathrm{O}_{1}$ & $\mathrm{X}$ & $\mathrm{O}_{2}$ \\
\hline
\end{tabular}

The population in this study is the students on sixth semester in Physics Education field study who program micro-teaching courses. The sample used was obtained by using purposes sampling with a total of 31 students. Data collection was carried out before and after treatment in accordance with the research variables. The instruments and techniques of collecting data are shown in Table 2.

Tabel 2. Data, Methods and Research Instruments

\begin{tabular}{ccc}
\hline Data & Method & Instrument \\
\hline Teaching confidence & Questionnaire & Questionnaire Sheet \\
Teaching Skills & Performance assessmentc & Rubric assessment \\
\hline
\end{tabular}

The effect of LCMT on teaching confidence and teaching skills analyzed through normalized-gain and compare mean by using t-test. Normalized-gain of pretest and postest (N-Gain) was formulated by Steward and Steward [25]:

$$
N-\text { Gain }=\frac{\text { posttest }- \text { pretest }}{\text { Skormax-pretest }}
$$

Range of N-Gain described by Wahyu, et. al [26] in Table 3:

Tabel 3. Normalized-Gain Classification and Criteria

\begin{tabular}{cc}
\hline Gain Score & Criteria \\
\hline $0,7<$ N_Gain & High \\
$0,3 \leq$ N_Gain $\leq 0,7$ & Moderate \\
N_Gain $<0,3$ & Low \\
\hline
\end{tabular}

Normalized data tested by using Kolmogorov-Smirnov and compare mean of pretest and posttest tested by using paired sample tests. Both of these tests calculated through SPSS version 21.

\section{RESULTS AND DISCUSSIONS}

Results

Teaching confidence data were obtained using a questionnaire before and after treatment. This teaching confidence data is displayed in the form of scores obtained from 31 individuals as shown in Table 4. Table 4 shows the difference in mean scores after and before treatment of 0.7026 and the results of the calculation of $\mathrm{N}-\mathrm{g}$ is 0.535 in the medium category. The results of the difference in scores and gains are positive and an increase in student teaching confidence through the LCMT model. 
The Effect of Distance Learning With Learner Center Micro Teaching Model... Adrianus Nasar, Melkyanus Bili Umbu Kaleka

Tabel 4. Descriptive Statistics of Teaching Confidence

\begin{tabular}{cccccc}
\hline & $\mathbf{N}$ & Minimum & Maximum & Mean & Std. Deviation \\
\hline Pre & 31 & 2,53 & 4,67 & 3,6868 & 0,46724 \\
Post & 31 & 3,60 & 4,87 & 4,3894 & 0,31892 \\
\hline
\end{tabular}

Teaching confidence score data is tested for normality and the results are as shown in Table 5. Based on Tabel 5, the results of normality test scores before treatment for the teaching confidence variable obtained $p=0.116$ for the Kolmogorov-Smirnov test and $p=0.058$ in Shapiro-Wilk, the results of the normality score test after treatment for the teaching confidence variable were obtained $p=0.200$ for the Kolmogorov-Smirnov test and $p=0.325$ at Shapiro-Wilk. Based on the results of the normality test above shows that $\mathrm{p}>0.05$, so $\mathrm{H}_{0}$ is accepted and $\mathrm{H}_{1}$ is rejected. Thus, data before and after treatment for teaching confidence variables meet the requirements of normal distribution.

Tabel 5. Tests of Normality of Teaching Confidence

\begin{tabular}{|c|c|c|c|c|c|c|}
\hline & \multicolumn{3}{|c|}{ Kolmogorov-Smirnov } & \multicolumn{3}{|c|}{ Shapiro-Wilk } \\
\hline & Statistic & df & Sig. & Statistic & df & Sig. \\
\hline Pre & 0,142 & 31 & 0,116 & 0,935 & 31 & 0,058 \\
\hline Post & 0,104 & 31 & $0,200 *$ & 0,962 & 31 & 0,325 \\
\hline \multicolumn{7}{|c|}{ *. This is a lower bound of the true significance. } \\
\hline \multicolumn{7}{|c|}{ a. Lilliefors Significance Correction } \\
\hline
\end{tabular}

The t-test of the effect of the LCMT model on teaching confidence using SPSS application looks the following Table 6 .

Tabel 6. Paired Samples Test

Paired Differences

\begin{tabular}{cccccccccc} 
& Mean & $\begin{array}{c}\text { Std. } \\
\text { Deviation }\end{array}$ & $\begin{array}{c}\text { Std. Error } \\
\text { Mean }\end{array}$ & $\begin{array}{c}\text { 95\% Confidence } \\
\text { Interval of the } \\
\text { Difference } \\
\text { Lower }\end{array}$ & Upper & t & df & $\begin{array}{c}\text { Sig. (2- } \\
\text { tailed) }\end{array}$ \\
\hline Pair 1 & $\begin{array}{c}\text { Post - } \\
\text { Pre }\end{array}$ & 0,70258 & 0,31711 & 0,05695 & 0,58626 & 0,81890 & 12,336 & 30 & 0,000 \\
\hline
\end{tabular}

Based on Tabel 6, t-test results for teaching confidence obtained $t=12.336$ and sig. (2-tailed) $=0,000$ $(\mathrm{p}<0.05)$. This shows that $\mathrm{H}_{0}$ is rejected and $\mathrm{H}_{1}$ is accepted. Thus, there is an effect of the application of the LCMT model on teaching.

Data of teaching skills before treatment was obtained through a performance assessment on the video of the results of teaching practices before applying the LCMT model. Data on teaching skills after treatment was obtained through an assessment of the video on the results of teaching practice after applying the LCMT model. The teaching skills data are described in the following Table 7.

Tabel 7. Descriptive Statistics

\begin{tabular}{cccccc}
\hline & N & Minimum & Maximum & Mean & Std. Deviation \\
\hline Pre & 31 & 2,28 & 3,96 & 3,1445 & 0,46377 \\
Post & 31 & 3,52 & 4,84 & 4,1948 & 0,39903 \\
Valid N (listwise) & 31 & & & & \\
\hline
\end{tabular}

Based on Table 7, it can be seen that the real difference of average scores before and after treatment is 1.0503 and the normalized gain, $\mathrm{N}$-gain $=0.5660$, which is in the medium category. From these results, 
shows that the difference between the real mean and normalized gain is positive, meaning that there is an increase in the mean scores of students' teaching skills.

Data normality test results before and after treatment for the teaching skills variable can be shown in Table 8 .

Tabel 8. Tests of Normality of Teaching Skills

\begin{tabular}{|c|c|c|c|c|c|c|}
\hline & \multicolumn{3}{|c|}{ Kolmogorov-Smirnov ${ }^{a}$} & \multicolumn{3}{|c|}{ Shapiro-Wilk } \\
\hline & Statistic & df & Sig. & Statistic & df & Sig. \\
\hline Pre & 0,081 & 31 & $0,200^{*}$ & 0,973 & 31 & 0,611 \\
\hline Post & 0,103 & 31 & $0,200^{*}$ & 0,948 & 31 & 0,140 \\
\hline \multicolumn{7}{|c|}{ *. This is a lower bound of the true significance. } \\
\hline
\end{tabular}

Based on Table 8 the results of the normality test data of teaching skills scores before treatment sig. $=$ 0,200 in the Kolmogorov-Smirnov test and sig. $=0.611$ in the Shapiro-Wilk test. The results of the normality test data on teaching skills scores after treatment sig. $=0,200$ in the Kolmogorov-Smirnova test and sig. $=0.140$ in the Shapiro-Wilk test. Because the results $p>0.05$, then $\mathrm{H}_{0}$ is accepted and $\mathrm{H}_{1}$ is rejected, thus both data before and after treatment for teaching skills meet normality test requirements. Tests for improving teaching skills are shown in Table 9.

Tabel 9. Paired Samples Test

\begin{tabular}{cccccccccc}
\hline & \multicolumn{8}{c}{ Paired Differences } & \multicolumn{2}{c}{ Std. } & \multicolumn{2}{c}{ 95\% Confidence Interval } \\
& Mean & $\begin{array}{c}\text { Std. } \\
\text { Deviation }\end{array}$ & $\begin{array}{c}\text { Std. } \\
\text { Error } \\
\text { Mean }\end{array}$ & $\begin{array}{c}\text { of the Difference } \\
\text { Lower }\end{array}$ & Upper & df & $\begin{array}{c}\text { Sig. (2- } \\
\text { tailed) }\end{array}$ \\
\hline Pair 1 & $\begin{array}{c}\text { Post - } \\
\text { Pre }\end{array}$ & 1,05032 & 0,60352 & 0,10840 & 0,82895 & 1,27170 & 9,690 & 30 & 0,000 \\
\hline
\end{tabular}

Based on Table 9, the t-test results for teaching skills obtained $t=9,690$ and sig. (2-tailed) $=0,000$ (p $<0.05$ ), thus $\mathrm{H}_{0}$ is rejected and $\mathrm{H}_{1}$ is accepted. It can be concluded that there is an effect of the application of the LCMT model on students' teaching skills.

\section{Discussions}

Micro teaching is a form of teaching that is very efficient and effective in improving one's teaching skills. Micro teaching that applies the principle of active learning through LCMT allows students to observe, reflect, form abstractions, and produce in their learning process. In addition, through LCMT, students apply critical, reflective, and creative thinking skills in planning and implementing learning. Students try to think about how to use pedagogical knowledge to implement content. Students connect their content knowledge (what they know about what they teach) to their pedagogical knowledge (what they know about teaching) and how content knowledge becomes part of their pedagogical reasoning.

The process of micro teaching involves steps such as planning, opening lessons, presenting, stimulating variations, using appropriate audio, reinforcement, questions, body language, and closing lessons. Micro teaching is not an activity that can be restricted to students, but a social process that involves instructors and peers. In addition to social processes, micro teaching also integrates the use of video technology to record teaching activities. Students can watch themselves while teaching through video playback.

The instructor and video recording are sources of feedback for students in the teaching process. Micro teaching allows students to get feedback from instructors which will give students more potential opportunities to correct mistakes and learn from making mistakes [27]. Students who watch their own presentation videos are useful in self-introspection and reflection on their teaching performance. The results showed that, the feedback from watching video presentations of teaching was useful in improving 
The Effect of Distance Learning With Learner Center Micro Teaching Model... Adrianus Nasar, Melkyanus Bili Umbu Kaleka

teaching skills [28]. Positive feedback such as encouraging students to improve themselves, dare to speak and act correctly will increase teaching confidence [29]. The reflective process in micro teaching can enable students to increase self-confidence, so that the reflection process can increase student selfconfidence. So, it can be concluded that distance learning with the LCMT model can increase teaching confidence of students.

Micro learning as an effective program for developing teaching skills of prospective teacher students. The implementation of micro teaching requires some knowledge and understanding to support teaching activities. The skills developed in micro teaching include skills that attract students' attention, use learning strategies, and manage classrooms. Students use their thinking skills in planning and implementing learning on a small scale and are able to evaluate them independently through the reflective thinking process. Feedback from the lecturer through distance learning helps him correct mistakes in the learning process. Therefore, it can be concluded that distance learning with the LCMT model can affect on students' teaching skills. The result is in line with the results of a study conducted by Ralf, where micro teaching has the potential to be a powerful instructional approach [30].

\section{CONCLUSION AND SUGGESTION}

Miro teaching course learning during the covid-19 pandemic period is carried out through distance learning. Lecturers and students do not meet in normal classrooms but through online networks. Students actively learn in using their thinking skills to produce learning designs and are implemented in the micro teaching process. The results of the study can be concluded that the application of distance learning through the LCMT model can improve teaching confidence and teaching skills of students of the Physics Education Department at the Faculty of Teacher Training and Education in the University of Flores. The practice of micro teaching is an important stage in the professional development of prospective teacher students and it provides an opportunity for prospective teacher students to apply content knowledge and pedagogical knowledge they learn on campus to the real classroom

\section{ACKNOWLEDGMENTS}

Special thanks go to fellow lecturers and students of the Physics Education Faculty of Teacher Training and Education at the University of Flores who have been involved in giving thoughts and taking part in research on the effect of distance learning through the micro teaching learner center (LCMT) model on teaching confidence and teaching skills.

\section{REFERENCES}

[1] Azrai, E. P., Rini, D. S., \& Suryanda, A. (2020). Micro-teaching in the Digital Industrial Era 4.0: Necessary or Not?. Universal Journal of Educational Research, 8(4A): 23-30.

[2] Ping, W. (2013). Micro-teaching: a powerful tool to embedding the English teacher certification testing in the development of English teaching methodologies. International Journal of English Language and Literature Studies, 2(3): 163-175.

[3] Bušelić, M. (2012). Distance Learning-concepts and contributions. Oeconomica Jadertina, 2(1): 23-34.

[4] Bağatur, S. (2015). Dismayed or enchanted: ELT students' perceptions towards microteaching. Procedia-Social and Behavioral Sciences, 199: 770-776.

[5] Remesh, A. (2013). Microteaching, an efficient technique for learning effective teaching. Journal of research in medical sciences: the official journal of Isfahan University of Medical Sciences, 18(2): 158. 
[6] Mahmud, I., \& Rawshon, S. (2013). Micro teaching to improve teaching method: An analysis on students' perspectives. IOSR Journal of Research \& Method in Education (IOSR-JRME), 1(4): 2320-7388.

[7] Altakhyneh, B. H. (2016). Effectiveness of using Microteaching and Thinking style to Develop Teaching Skills in Arab Open University-Jordan Branch. International Journal of Learning, Teaching and Educational Research, 15(3).

[8] Herrera, R. F., Vielma, J. C., \& La Rivera, F. M. O. (2018). Impact of Microteaching on Engineering Students' Communication Skills. The International journal of engineering education, 34(6): 1768-1775.

[9] Reddy, K. R. (2019). Teaching how to teach: microteaching (a way to build up teaching skills). Journal of Gandaki Medical College-Nepal, 12(1): 65-71.

[10] Kilic, A. (2010). Learner-Centered Micro Teaching in Teacher Education. Online Submission, 3(1): 77-100.

[11] Dagar, V., \& Yadav, A. (2016). Constructivism: A paradigm for teaching and learning. Arts and Social Sciences Journal, 7(4): 1-4.

[12] Bilen, K. (2015). Effect of micro teaching technique on teacher candidates' beliefs regarding mathematics teaching. Procedia-Social and Behavioral Sciences, 174: 609-616.

[13] Christensen, R., Knezek, G., Tyler-Wood, T., \& Gibson, D. (2011). SimSchool: An online dynamic simulator for enhancing teacher preparation. International Journal of Learning Technology, 6(2): 201-220.

[14] Ünlü, M. (2018). Effect of Micro-Teaching Practices with Concrete Models on Pre-Service Mathematics Teachers' Self-Efficacy Beliefs about Using Concrete Models. Universal Journal of Educational Research, 6(1): 68-82.

[15] Sen, A. I. (2010). Effects of peer teaching and microteaching on teaching skills of pre-service physics teachers. Egitim ve Bilim, 35(155): 78.

[16] Onwuagboke, B. B. C., Osuala, R. C., \& Nzeako, R. C. (2017). The impact of microteaching in developing teaching skills among pre-service teachers in Alvan Ikoku College of Education Owerri, Nigeria. African Research Review, 11(2): 237-250.

[17] Savas, P. (2012). Micro-teaching videos in EFL teacher education methodology courses: Tools to enhance English proficiency and teaching skills among trainees. Procedia-Social and Behavioral Sciences, 55: 730-738.

[18] Karlström, M., \& Hamza, K. (2019). Preservice science teachers' opportunities for learning through reflection when planning a microteaching unit. Journal of Science Teacher Education, 30(1): 4462.

[19] Chawla, V., \& Thukral, P. (2011). Effects of student feedback on teaching competence of student teachers: A microteaching experiment. Contemporary Educational Technology, 2(1): 77-87.

[20] Al Darwish, S., \& Sadeqi, A. (2016). Microteaching impact on Student Teacher's Performance: A Case Study from Kuwait. Journal of Education and Training Studies, 4(8): 126-134.

[21] Bakır, S. (2014). The effect of microteaching on the teaching skills of pre-service science teachers. Journal of Baltic Science Education, 13(6): 789.

[22] Shukla, N. (2017). Microteaching: a comparative study of skill development of pupil teachers in relation to their gender. EPRA International Journal of Economic and Business Review, 5(11): 174179.

[23] Arsal, Z. (2015). The effects of microteaching on the critical thinking dispositions of pre-service teachers. Australian Journal of Teacher Education, 40(3): 9.

[24] Bakır, S. (2014). The effect of microteaching on the teaching skills of pre-service science teachers. Journal of Baltic Science Education, 13(6): 789.

[25] Stewart, J., \& Stewart, G. (2010). Correcting the normalized gain for guessing. The Physics 
Teacher, 48(3): 194-196.

[26] Wahyu, W., \& Syaadah, R. S. (2018). Implementation of problem-based learning (PBL) approach to improve student's academic achievement and creativity on the topic of electrolyte and nonelectrolyte solutions at vocational school. JPhCS, 1013(1): 012096.

[27] Albin, S., \& Shihomeka, S. P. (2017). Learning from students' experiences of microteaching for numeracy education and learning support: a case study at University of Namibia, Southern campus. American Scientific Research Journal for Engineering, Technology, and Sciences (ASRJETS), 36(1): 306-318.

[28] Dayanindhi, V. K., \& Hegde, S. P. (2018). Effectiveness of microteaching as a method of developing teaching competence among in-service medical teachers. Journal of Advances in Medical Education \& Professionalism, 6(4): 155.

[29] Rahimi, A. (2019). Investigating the Contributing Factors Affecting High School Students' Selfconfidence and the Solutions for Enhancement: A Case Study of Arabu Qala High School, Kandahar, Afghanistan. American International Journal of Social Science Research, 4(1): 35-45.

[30] Ralph, E. G. (2014). The effectiveness of microteaching: Five years' findings. International Journal of Humanities Social Sciences and Education, 1(7): 17-28. 